\title{
Graft type for superior mesenteric and portal vein reconstruction in pancreatic surgery
}

- A systematic review

Knut Jørgen Labori ${ }^{1} \mathrm{MD} \mathrm{PhD}$

Dyre Kleive ${ }^{1} \mathrm{MD} \mathrm{PhD}$

Ammar Khan ${ }^{2,3} \mathrm{MD}$

Ingvild Farnes ${ }^{1,3} \mathrm{MD}$

Bjarte Fosby² MD PhD

Pål-Dag Line ${ }^{2,3}$ MD PhD

${ }^{1}$ Department of Hepato-Pancreato-Biliary Surgery, Oslo University Hospital, Rikshospitalet, Oslo, Norway

${ }^{2}$ Department of Transplantation Medicine, Oslo University Hospital, Rikshospitalet, Oslo, Norway

${ }^{3}$ Institute of Clinical Medicine, University of Oslo, Oslo, Norway

Correspondence/reprints addressed to: Knut Jørgen Labori, MD PhD, Nydalen 0424, Oslo, Norway Telephone: + 47 23070000, Fax number: +47 23072526 E-mail: uxknab@ ous-hf.no

Funding: This work was supported by the South-Eastern Norway Regional Health Authority [grant numbers 2018088 and 2019029] 


\section{ABSTRACT}

Background: Contemporary practice for superior mesenteric/portal vein (SMV-PV) reconstruction during pancreatectomy with vein resection involves biological (autograft, allograft, xenograft) or synthetic grafts as a conduit or patch. The aim of this study was to systematically review the safety and feasibility of the different grafts used for SMVPV reconstruction. Methods: A systematic search was performed in PubMed and Embase according to the PRISMA guidelines (January 2000-March 2020). Studies reporting on $\geq 5$ patients undergoing reconstruction of the SMV-PV with grafts during pancreatectomy were included. Primary outcome was rate of graft thrombosis. Results: Thirty-four studies with 603 patients were included. Four graft types were identified (autologous vein, autologous parietal peritoneum/falciform ligament, allogeneic cadaveric vein/artery, synthetic grafts). Early and overall graft thrombosis rate was $7.5 \%$ and $22.2 \%$ for synthetic graft, $5.6 \%$ and $11.7 \%$ for autologous vein graft, $6.7 \%$ and $8.9 \%$ for autologous parietal peritoneum/falciform ligament, and $2.5 \%$ and $6.2 \%$ for allograft. Donor site complications were reported for harvesting of the femoral, saphenous, and external iliac vein. No cases of graft infection were reported for synthetic grafts. Conclusion: In selected patients, autologous, allogenic or synthetic grafts for SMV-PV reconstruction are safe and feasible. Synthetic grafts seems to have a higher incidence of graft thrombosis. 


\section{INTRODUCTION}

Pancreatectomy with superior mesenteric/portal vein (SMV-PV) resection is considered standard of care in patients with pancreatic and periampullary tumours with involvement of the SMV-PV and a reconstructable vein. Several studies have been published on pancreatectomy with SMV-PV resection, but results related to technical aspects of the vascular resection and the rate of graft thrombosis are often not reported as the key outcomes of these studies. For patients with pancreatic cancer, Ravikumar et al showed that the type of venous reconstruction did not affect long-term survival ${ }^{[1]}$. Thus, the optimal method for venous reconstruction is the one that provides the greatest chance of a safe R0/R1 resection of the tumour ${ }^{[1,2]}$. Several different approaches are reported, and centres have different preferences. Primary end-to-end anastomosis and venorrhaphy are reportedly used in $20-83 \%$ and $15-56 \%$ of patients, respectively ${ }^{[3]}$. When primary anastomosis is difficult to achieve due to tension and the risk of stenosis, different types of grafts have been used. No consensus exists on the optimal graft for SMV-PV reconstruction ${ }^{[4]}$. Contemporary practice involves biological (autograft, allograft, xenograft) or synthetic grafts as a conduit or patch for segmental or partial vein wall reconstructions. Some centres advocate that a graft may be avoided in most cases ${ }^{[5,6]}$. Comparative trials are scarce, and daily decisions are often made using low-quality evidence.

Surgery with venous resection for pancreatic cancers has been proven comparable to surgery without venous resection in terms of perioperative outcome and long-term survival. The major concerns with SMV-PV resection and reconstruction with a graft are graft thrombosis and long term patency. Even though there are no large studies available some specific concerns have been raised. Synthetic grafts are anticipated to have a higher risk of thrombosis and infection, the use of autologous venous grafts is at risk of complications related to the donor site, and cadaveric allografts may be in risk of rejection ${ }^{[5]}$. The aim of this 
study was to assess the safety and feasibility of the different grafts used for SMVPV reconstruction during pancreatic surgery and to determine potential benefits of the different types of grafts considering the rate of graft thrombosis as primary outcome.

\section{METHODS}

\section{Systematic literature search and selection}

Adhering to the 2009 PRISMA guidelines, a systematic search was performed in PubMed and Embase for articles published from January 2000 to March $2020^{[7]}$. First author screened articles by title and abstract and, if applicable, the full articles for eligibility based on predefined inclusion and exclusion criteria. The search was restricted to studies on humans and studies published in languages other than English were excluded. Reference lists of all included papers and related articles were screened manually to identify missed but relevant studies. If there was any doubt about the suitability of the studies after reading the titles and abstracts, the full articles were obtained for detailed evaluation, and all eligible studies were included. The following search terms were used ${ }^{[8]}$ : (pancreatoduodenectomy OR pancreaticoduodenectomy OR duodenopancreatectomy OR pancreatectomy OR pancreatic resection) AND (vein resection OR vascular resection $\mathrm{OR}$ vein reconstruction $\mathrm{OR}$ vascular reconstruction) AND (vein grafts OR vascular grafts OR grafts).

\section{Eligibility criteria}

Included were studies concerning reconstruction of SMV-PV reporting on the incidence of graft thrombosis. Excluded were studies with fewer than 5 relevant patients, review articles, meta-analysis, and published conference abstracts.

\section{Data extraction}


All selected studies were evaluated for relevant patients, defined as patients undergoing pancreatic resection with SMV-PV resection and reconstruction with a graft. Study design, sample size and data on early and late graft thrombosis, graft patency, graft infection, morbidity, mortality, complications related to donor site, radiological surveillance modality and anticoagulation policy were extracted. Mortality was defined as death within 30days of surgery or as in-hospital mortality.

\section{Quality assessment}

The methodological quality of the included non-randomized studies was assessed by using the Newcastle-Ottawa Scale (NOS) ${ }^{[9]}$. NOS includes three domains 'selection of patients', 'comparability of study groups' and 'assessment of outcome'. In this systematic review, the parts of the NOS score ('selection of the non-exposed'=S2, and 'comparability' $=\mathrm{C} 1+\mathrm{C} 2$ ) were not applicable, because of its descriptive nature. For studies with no relevant data accordingly to NOS items $\mathrm{S} 2$ and $\mathrm{C} 1+\mathrm{C} 2$ for appraisal, we noted them as "not relevant" (NR). Thus, each study could not be evaluated and rated on the NOS 0-9 scale, but was ranked with a maximum of 6 points.

\section{Statistical analysis}

Results and outcomes in tables are expressed as they were originally reported. No meta-analysis was performed because of heterogeneity between studies. Hence, no statistical analysis was done owing to variation in the outcomes reported and variation of treatments used.

\section{RESULTS}

The systematic search identified 34 studies, all retrospective cohort studies, comprising 603 patients undergoing pancreatectomy with SMV-PV resection and 
reconstruction with a graft. No randomized trials were available. A PRISMA flow diagram is shown in Figure 1. Many of these retrospective studies failed to provide a detailed description of how graft thrombosis was assessed by means of radiological surveillance strategy (modality, time intervals) (Table 1-4). This produced an overall assessment of moderate quality according to NOS (Table S1, supporting information).

Four hundred and fifty-five patients underwent pancreatoduodenectomy, 19 patients total pancreatectomy, 20 patients distal pancreatectomy, and in 109 patients the type of pancreatectomy was not specified. Type of graft used for SMV-PV reconstruction was autologous vein in 239 patients (left renal vein 39, saphenous vein 44, femoral vein 38, internal jugular vein 32, external iliac vein 50, and other veins 36 (gonadal, inferior mesenteric, splenic vein or not specified), synthetic graft in 158 patients (polytetrafluoroethylene (PTFE): 150, polyester: 8), cadaveric allografts in 161 patients (vein: 150, artery: 11), falciform ligament in 27 patients, and parietal peritoneum in 18 patients. Interposition graft was performed in 435 patients, patch in 123 patients, and details about the procedure were not specified in 45 patients (Table 1- 4).

The incidence of early graft thrombosis ( $<30$ days) was $7.5 \%$ for synthetic grafts, 5.6 $\%$ for autologous veins, $6.7 \%$ for parietal peritoneum/falciform ligament, and $2.5 \%$ for cadaveric allografts. The overall incidence of graft thrombosis was $22.2 \%$ for synthetic grafts, $11.7 \%$ for autologous veins, $8.9 \%$ for parietal peritoneum/falciform ligament, and 6.2 $\%$ for cadaveric allografts. If patients with locoregional recurrence and concomitant late graft thrombosis were excluded the overall incidence of graft thrombosis was $16.4 \%$ for synthetic grafts, $11.7 \%$ for autologous veins, $8.9 \%$ for parietal peritoneum/falciform ligament, and 4.3 $\%$ for cadaveric allografts. The postoperative surveillance strategy varied between studies. The radiological follow up most often consisted of Doppler ultrasound during the first postoperative days and CT in case of symptoms during hospital stay and during post- 
discharge follow up. In some cases MR venography was used. There was no consistent definition of graft patency. Terms as "patent", "no occlusion", "no stenosis" or "no thrombosis" were commonly used to define graft patency. Some studies defined patency as grade of stenose (\%) comparing the diameter of the reconstructed SMV-PV with the preoperative diameter.

In-hospital/30-days mortality was $2.7 \%$ for synthetic grafts, $2.7 \%$ for autologous veins, $0 \%$ for parietal peritoneum/falciform ligament, and $3.2 \%$ for cadaveric allografts. Overall 30-day/in-hospital mortality was $2.7 \%$ (13/489). Only three postoperative deaths were reported to be caused by acute, early SMV-PV thrombosis (3/27, $11.1 \%)$. Morbidity was classified according to the Clavien-Dindo if applicable, and are presented in Table 1-4. There were no reports of graft infection with the use of synthetic grafts. Two studies reported transient elevated serum creatinine levels during postoperative day 1-3 after left renal vein harvest. Four studies reported postoperative edema, deep venous thrombosis or chronic pain in ipsilateral leg after external iliac vein or femoral/saphenous vein harvest.

Antiplatelet and anticoagulant protocols varied extensively between studies, and in some cases within the same study as choice of therapy was at surgeons discretion. Six studies reported that postoperative anticoagulation was not routinely recommended. Fourteen studies recommended LMWH, heparin or oral warfarin during hospital stay, and in some centres anticoagulation was continued after discharge. Fourteen studies recommended daily acetyl salicylic acid for 3-6 months. 


\section{DISCUSSION}

This systematic review of 603 patients undergoing pancreatectomy with SMV-PV resection has shown that the use of autografts, allografts or synthetic grafts for SMVPV reconstruction appears to be safe and feasible in selected patients. Graft thrombosis do occur with all types of grafts (early $2.5 \%-7.5 \%$, overall $6.2-22.2 \%$ ), but synthetic grafts seems to have a higher incidence of graft thrombosis. The studies had a substantial risk of selection bias, and the choice of graft are most likely made on basis of surgeon and/or centre preferences. No uniform definition of long term graft patency was found. The studies varied extensively regarding the postoperative follow-up imaging and anticoagulation protocols.

Some authors prefer to avoid synthetic grafts due to an anticipated higher risk of thrombosis and infection compared with native grafts ${ }^{[5]}$. The data from this review indicate that graft thrombosis is more likely after synthetic graft reconstruction, but an association with increased mortality was not shown. None of the 10 studies reported any cases of graft infection with synthetic grafts. Only three of the 10 studies made specific comments on how to avoid graft infection. Administration of perioperative antibiotics, graft immersion in antibiotic solution, avoidance of enteric and biliary spillage, placement of an omental wrap, and use of antibiotic irrigant, albeit unquantitated in efficacy, were all suggested as potential means of minimizing infection ${ }^{[10-12]}$.

Overall 30-day/in-hospital mortality in this systematic review was $2.6 \%$ (13/494). Most studies reported all-cause mortality as opposed to venous reconstruction type or early SMV-PV thrombosis associated mortality. Chandrasegaram et al showed that the overall mortality associated with early SMV-PV thrombosis after pancreatectomy with or without grafts was $40 \%(8 / 20)$ compared to $11.1 \%(3 / 27)$ in this systematic review after pancreatectomy with grafts ${ }^{[11,13-15]}$. Kantor et al analyzed 640 patients undergoing 
pancreatoduodenectomy with venous resection in the American College of Surgeons National Surgical Quality Improvement Project from 2006 to $2013^{[16]}$. Of these 224 patients had a graft repair that was associated with increased overall morbidity $(58.7 \%, \mathrm{p}<0.01)$ and 30-day mortality rates $(21 \text { of } 229,7.7 \%, \mathrm{p}<0.01)^{[16]}$. Although based on small study samples, SMVPV graft thrombosis seems to be a significant event and is associated with a mortality of $>10$ $\%$.

A recent survey showed that most surgeons prefer a segmental resection with primary anastomosis or a partial venous excision with direct closure, and thought that SMV-PV reconstruction with a conduit carries the highest risk of complications ${ }^{[4]}$. This systematic review shows that studies on the use of autologous veins and synthetic grafts were published from 2006 to 2019, whereas studies on cadaveric allografts and parietal peritoneum/falciform ligament were published from 2013 to 2019 and 2015 to 2019, respectively. During the last ten years several centres have also advocated that a graft may be avoided in most cases ${ }^{[5,6]}$. Thus, there seems to have been some reconsiderations of type of graft and reconstruction methods during time. Over the last decade, advancements in preoperative chemotherapy and radiation therapy in pancreatic cancer have led to expansion of indications for surgical resection in patients with borderline resectable and locally advanced pancreatic cancer. Whether this will affect the choice of SMV-PV reconstruction remains to be established. Of note, recently a novel approach with SMV-PV resection without reconstruction has been introduced in patients with significant venous collaterals ${ }^{[17]}$.

The stability of the patient may play a role, and more urgent clinical conditions may lead to the use of prosthetic grafts or cadaveric allografts to decrease the operative time ${ }^{[3,18]}$. Cadaveric allografts are easy available in some centres, and is likely to save operative time. In a recent study, donor-specific allosensitization after allogeneic venous reconstruction of the SMV-PV has been documented ${ }^{[19]}$. Moreover, PV transplantation in mice have revealed full 
thickness infiltration of the vascular wall with mononuclear cells and moderate destruction of the endothelium and tunica media at postoperative week 1 with significantly reduced luminal diameter and intimal thickening on the 4 th postoperative week ${ }^{[20]}$. Thus, an immune mediated phenomenon in reconstruction with cadaveric vein allografts cannot be excluded. The nine studies on the use of cadaveric allografts had similar rate of graft thrombosis and as good long term graft patency as other biological grafts, and no studies reported any kind of immunosuppression or steroid therapy. Short term low level immunosuppression could possibly be of value after SMV-PV reconstruction with allogenic grafts to mitigate the allogeneic immuneresponse. The level and duration of immunosuppression has to be balanced against the risk of side effects and possible impact on complications like pancreatic fistula. One possible strategy could be a course of corticosteroids with or without mycophenolate mofetil with gradual weaning in the course of a few weeks, but no data are available with regards to the routine use of immunosuppressants, specific agents or duration in this particular setting.

Autologous vein harvesting is associated with an additional surgical procedure carried out at another site of the body, disruption of the main operation, and prolonged operative time. Left renal vein is easily exposed during the abdominal dissection, and an additional incision is not required to access $\mathrm{it}^{[21]}$. Two studies reported transient elevated serum creatinine levels during postoperative day 1-3 after left renal vein harvest ${ }^{[21,22]}$. Two studies reported no increase in creatinine levels, and demonstrated collateral venous drainage from the left kidney by $\mathrm{CT}^{[23,24]}$. Thus, the left renal vein may be excised without compromising venous return from the left kidney if the adrenal and gonadal veins are preserved. Several studies reported postoperative edema or deep venous thrombosis in ipsilateral leg associated with external iliac vein or femoral/saphenous vein harvest ${ }^{[25-28]}$. Some centres have even presented reconstruction techniques of the external iliac vein to overcome this 
complication $^{[29]}$. In addition, there were some reports of seroma and wound dehiscence in the groin associated with harvesting of femoral/saphenous vein ${ }^{[25,30]}$.

The parietal peritoneum is considered as a rapidly available option for vascular reconstruction, especially for unplanned lateral reconstruction of the SMV-PV with the need of a patch, whereas the falciform ligament has been suggested as an option in case of the need of an interposition graft ${ }^{[31-34]}$. Other types of reconstruction revealed during the search was xenografts (bovine pericardium) or recanalized umbilical vein (Mesorex), but the reports in the literature were based on case reports or small case series ${ }^{[35,36]}$.

Song et al performed a metaanalysis of relevant trials comparing vein grafts versus no vein grafts during pancreatoduodenectomy with venous resection and found 14 studies including 257 patients with vein grafts and 570 patients without vein grafts ${ }^{[8]}$. They found a lower long-term vein patency rate in patients with vein grafts indicating that interposition grafts may be more likely to lose function. However, there are no randomized controlled trials and only a few comparative trials designed to compare different reconstruction techniques. Kleive et al showed that reconstruction of the SMV-PV with allograft was associated with longer operative time and more perioperative bleeding compared with primary end-to-end anastomosis $^{[19]}$. Preoperative CT images revealed that allograft reconstruction was performed in patients in whom a longer segment of the vein was affected by tumor $(2.4 \mathrm{~cm}$ versus 1.8 $\mathrm{cm}, \mathrm{p}=0.02$ ), and a higher proportion of patients had $>180$-degree tumour-vein interface (35.7\% versus $21.1 \%, \mathrm{p}=0.01)$. Zhang et al showed that patients undergoing reconstruction with allograft had a significant longer vein segment resected compared with patients undergoing primary end-to-end anastomosis $(3 \mathrm{~cm}$ versus $2 \mathrm{~cm}, \mathrm{p}>0.001)$. Liao et al also showed that patients receiving PTFE grafts for SMV-PV reconstruction had a longer vein segment resected ( $4 \mathrm{~cm}$ versus $2.9 \mathrm{~cm}, \mathrm{p}<0.001$ ), and in addition a larger tumour diameter $(3.4 \mathrm{~cm}$ versus $2.9 \mathrm{~cm}, \mathrm{p}=0.016)$ than patients undergoing primary end-to-end anastomosis ${ }^{[12]}$. 
Moreover, PTFE graft was associated with longer operative time and more perioperative bleeding. These studies suggest that resection and reconstruction in patients receiving grafts are technically more challenging, which may account for the longer operative time and more extensive perioperative bleeding. Moreover, the longer vein segment resected and the larger tumour diameter in patients receiving a graft may reflect the fact that the patients requiring interposed allograft had more locoregional advanced tumours. Thus, comparing patients receiving interposition grafts with a primary end-to-end anastomosis may not be justified. It is only recently, that a standardized radiology reporting template has been proposed for pancreatic ductal adenocarcinoma ${ }^{[37]}$. Although planned SMV-PV resections for pancreatic cancer were associated with higher rates of postoperative morbidity than unplanned resections, $\mathrm{R} 0$ resection rates were better ${ }^{[38]}$. The use of proper preoperative imaging would likely aid in peroperative planning, in particular regarding the SMV-PV resection part of the procedure.

This systematic review confirms that there is a lack of consensus on the definition and reporting of long term graft patency after pancreatic surgery with SMV-PV resection and reconstruction. Patency rates may be overestimated when using only occlusion and/or thrombosis as a definition for failed late graft patency. However, the need for long term evaluation of the SMV-PV reconstruction may be debated as several studies report disease recurrence as the most common cause of late graft thrombosis and stenosis ${ }^{[3,11,28,39]}$. Snyder et al found that $76 \%(19 / 25)$ of the cases of late SMV-PV thrombosis after vein resection with or without graft occured in the setting of locoregional recurrence ${ }^{[40]}$. Thus, late SMV-PV thrombosis is likely due to tumor biology causing tumor in-growth or compression on the area of previous vein resection, and less likely due to technical issues or graft type. Moreover, imaging findings of local recurrence can be difficult to distinguish from post-operative changes after SMV-PV reconstruction ${ }^{[41]}$. Some authors advocate that long-term patency of 
the SMV-PV should be examined, because long-term survivors who experience SMV-PV stenosis/occlusion may develop portal hypertension ${ }^{[42]}$. However, the therapeutic consequence of detecting an asymptomatic SMV-PV stenosis/occlusion is under debate. Due to increased risk of complications, the indication for percutaneous PV stent placement after pancreatectomy with venous resection and reconstruction is recommended to be limited to patients with clinical symptoms ${ }^{[42,43]}$. Most patients are asymptomatic, whereas others present with the typical clinical signs of portal hypertension, including gastrointestinal hemorrhage, ascites and splenomegaly ${ }^{[42]}$. Glebova et al showed that tumor recurrence played the dominant role in ascites development in cases of an associated SMV-PV thrombus ${ }^{[18]}$. However, ascites may also be the first sign of early postoperative SMV-PV occlusion and thrombus ${ }^{[11,32]}$.

Antiplatelet and anticoagulant protocols varied extensively between studies. This is in line with a systematic review showing that there is a significant heterogeneity in the use of anticoagulation/antiplatelet therapy after SMV-PV resection and reconstruction, with aspirin being a common minimum therapy for prophylaxis ${ }^{[15]}$. Chandrasegaram et al performed a systematic review on studies with an anticoagulation policy to no anticoagulation policy after venous resection during pancreatectomy and showed that early SMV-PV thrombosis rate was similar in the two groups ( $7 \%$ vs $3 \%)^{[15]}$. Kleive et al found no difference in the rate of early SMV-PV thrombosis (4.4\% vs $4.2 \%$ ) or postpancreatectomy hemorrhage (13.3\% vs $16.7 \%$ ) between patients receiving low- or high-dose low-molecular-weight heparin after pancreatoduodenectomy with venous resection and reconstruction ${ }^{[44]}$. Given the technical complexity and heterogeneity of these operations and the consequences of thrombosis, it would be difficult to standardize practice in the absence of a randomized prospective trial ${ }^{[45]}$. As suggested by Chandrasegaram, we agree that ideally the effects of antiplatelets or anticoagulants on graft patency should be investigated further in the context of a multicentre randomized controlled trial, and that such a study should include standardized definitions to 
describe the types of vascular resection and type of graft used. However, it may be difficult to elucidate whether the most important factor for graft thrombosis is type of graft, technical factors or anticoagulation policy.

The results of this systematic review should be interpreted in light of several limitations. Only retrospective cohort studies were identified, and no randomized trials were available. Moreover, the quality of included studies were moderate according to NOS. Despite these limitations, the presented results and outcomes of all available literature on the use of grafts for SMV-PV reconstruction during pancreatectomy allow for a better understanding and critical evaluation of this approach. In order to achieve high-level evidence regarding anticoagulation policy, optimal reconstruction technique and follow-up, future research must be established in a multicentre platform with standardized definitions and predefined selection criterias. 
Prisma flowchart, search 31 ${ }^{\text {th }}$ of March 2020

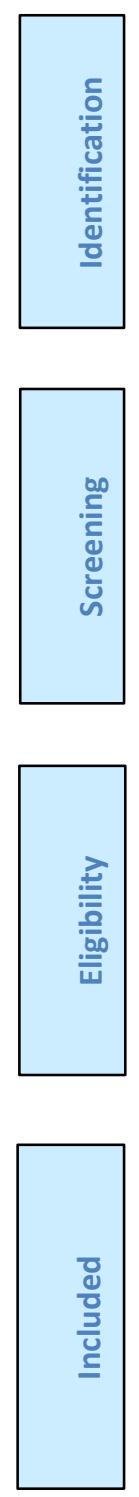

Articles identified through database searching

PubMed $(\mathrm{n}=461)$

EMBASE $(n=52)$
Additional records identified through other source

Checking reference for relevant articles $(n=6)$
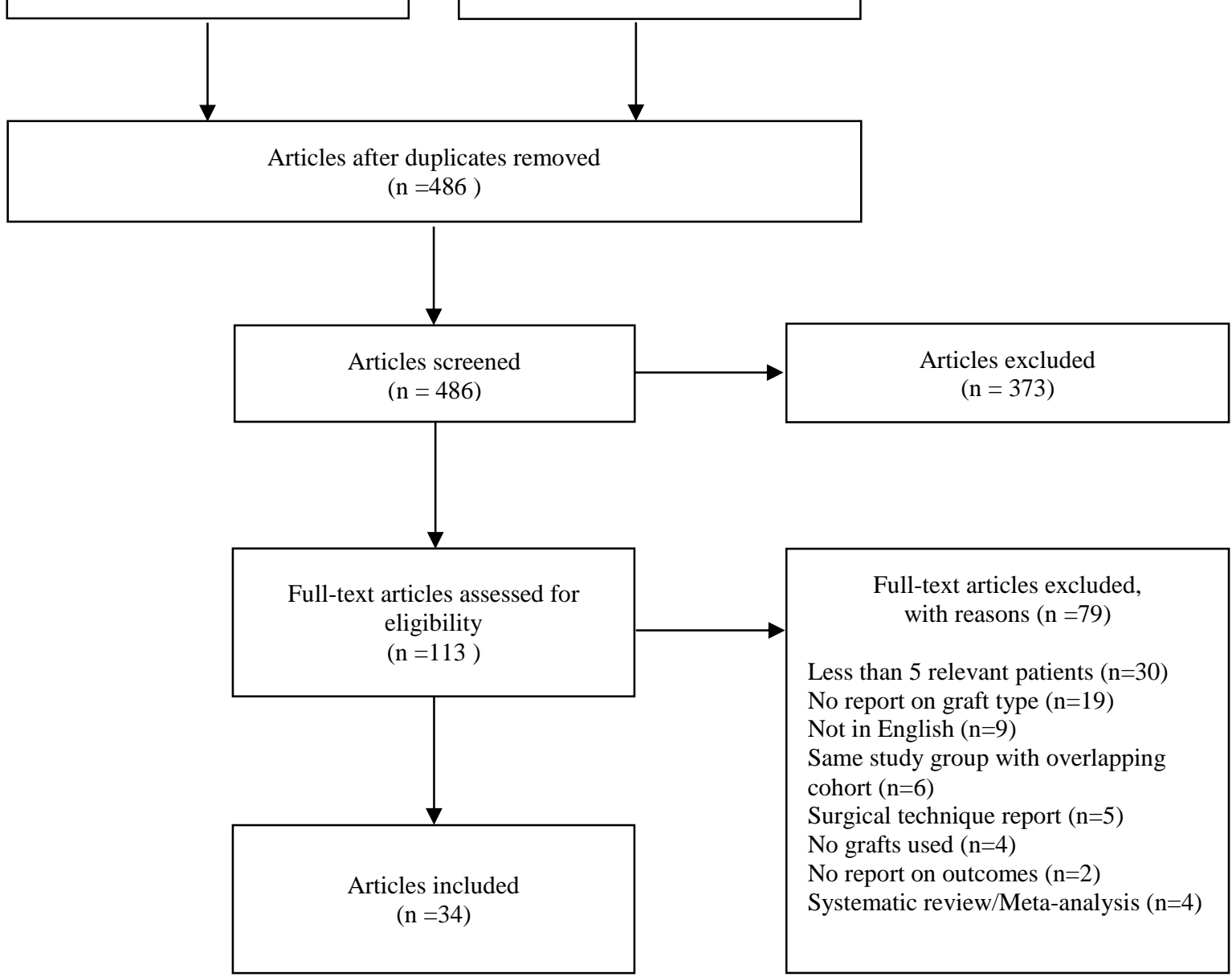


\section{TABLES}

\section{Table 1 Cadaveric vein or arterial allografts (9 studies)}

\begin{tabular}{|c|c|c|c|c|c|c|c|}
\hline Author/Year & $\begin{array}{l}\text { Graft type/ } \\
\text { Number of patients }\end{array}$ & Morbidity & Mortality & Graft thrombosis & Graft patency (\% or n)/Modality & Follow up & Anticoagulation \\
\hline $\begin{array}{l}\text { Zhang } \\
2013^{[46]}\end{array}$ & $\begin{array}{l}\text { Cadaveric portal vein } \\
\text { allograft } 3 / \text { Cadaveric iliac } \\
\text { artery allograft } 6 \\
\text { (interposition) }\end{array}$ & $3(\mathrm{CD} 1-3)$ & 0 & 0 & $\begin{array}{l}100 \% \\
\text { Doppler US, CT or MRI }\end{array}$ & Median 18.1 months & None \\
\hline $\begin{array}{l}\text { Mascoli } \\
2015^{[47]}\end{array}$ & $\begin{array}{l}\text { Cadaveric artery allograft } \\
5 \text { (aorta 3, femoral artery } 2 \text { ) } \\
\text { (interposition) }\end{array}$ & $2(\mathrm{CD} 3)$ & 0 & 0 & $\begin{array}{l}100 \% \\
\text { Doppler US }\end{array}$ & Median 10 months & $\begin{array}{l}\text { LMWH twice a day POD } 1-30 \text { according to } \\
\text { weight and blood clotting tests. } \\
\text { If platelets }>400 \times 10^{3} / \mu 1 \text {, antiplatelet therapy } \\
\text { was also administered. }\end{array}$ \\
\hline $\begin{array}{l}\text { Kleive } \\
2016^{[3]}\end{array}$ & $\begin{array}{l}\text { CIVA } 45 \\
\text { (interposition 37, patch 8) }\end{array}$ & $16(\mathrm{CD} \geq 3)$ & $\begin{array}{l}2 \\
\text { (in-hospital) }\end{array}$ & $\begin{array}{l}2(<30 \text { days }) \\
3 \text { ( }>30 \text { days, concomitant with } \\
\text { locoregional recurrence) }\end{array}$ & $\begin{array}{l}\text { Severe stenosis ( }>70 \% \text { stenosis vs } \\
\text { preoperative diameter, occlusion or } \\
\text { thrombus): } 26 \text { (of whom } 23 \text { had signs of } \\
\text { locoregional recurrence). } \\
\text { Doppler US, CT }\end{array}$ & Median 13 months & $\begin{array}{l}\text { LMWH } 200 \mathrm{IU} / \mathrm{kg} \text { first month, } 100 \mathrm{IE} / \mathrm{kg} \text { the } \\
\text { following two months. } \\
\text { Lifelong ACA } 75 \mathrm{mg} \text { daily at the surgeon's } \\
\text { discretion. }\end{array}$ \\
\hline $\begin{array}{l}\text { Zhao } \\
2016^{[48]}\end{array}$ & $\begin{array}{l}\text { CIVA 21 } \\
\text { (interposition) }\end{array}$ & $6(\mathrm{CD} 1-5)$ & $\begin{array}{l}1 \\
\text { (in-hospital) }\end{array}$ & $\begin{array}{l}0(<30 \text { days }) \\
2(>30 \text { days })\end{array}$ & $\begin{array}{l}\text { NS } \\
\text { Doppler US, CT }\end{array}$ & Mean 18.2 months & $\begin{array}{l}\text { LMWH } 2850 \text { IU twice daily first week, then } \\
\text { ACA } 100 \mathrm{mg} \text { daily for up to } 6 \text { months. }\end{array}$ \\
\hline $\begin{array}{l}\text { Meniconi } \\
2016^{[13]}\end{array}$ & $\begin{array}{l}\text { CIVA } 11 \\
\text { (interposition } 7, \text { patch } 4 \text { ) }\end{array}$ & $5(\mathrm{CD} 1-5)$ & 1 (30 days) & $\begin{array}{l}1(<30 \text { days, died }) \\
0(>30 \text { days })\end{array}$ & $\begin{array}{l}\text { No stenosis. } \\
\text { Doppler US, CT }\end{array}$ & Median 9 months & $\begin{array}{l}\text { LMWH (enoxaparin } 4000 \text { IU) daily for } 30 \\
\text { days. }\end{array}$ \\
\hline $\begin{array}{l}\text { Yamamoto } \\
2017^{[49]}\end{array}$ & $\begin{array}{l}\text { Cadaveric portal and } \\
\text { femoral vein allograft } 18 \\
\text { (interposition 11, patch 7) }\end{array}$ & $\begin{array}{l}5(\mathrm{CD} 1+2) \\
0(\mathrm{CD} \geq 3)\end{array}$ & 0 & $\begin{array}{l}0(<30 \text { days }) \\
1 \text { ( }>30 \text { days })\end{array}$ & $\begin{array}{l}\text { Clinically relevant stenosis }(>50 \% \\
\text { stenosis vs preoperative diameter): } 8 \\
\text { (pseudo-intimal hyperplasia in 5, local } \\
\text { recurrence in 3). } \\
\text { Doppler US, CT or MRI }\end{array}$ & Median 18 months & NS \\
\hline $\begin{array}{l}\text { Zhang } \\
2018^{[50]} \\
\end{array}$ & $\begin{array}{l}\text { CIVA 42 } \\
\text { (interposition) }\end{array}$ & $13(\mathrm{CD} 1-3)$ & $\begin{array}{l}0 \\
\text { (in-hospital) }\end{array}$ & 0 & $\begin{array}{l}\text { NS } \\
\text { Doppler US, CT }\end{array}$ & NS & $\begin{array}{l}\text { Nodroparin calcium } 0.4 \mathrm{mLx} 1 \text { POD } 2-7 \text {, } \\
\text { then daily ACA for } 1 \text { month. }\end{array}$ \\
\hline $\begin{array}{l}\text { Dumitrascu } \\
2018^{[51]}\end{array}$ & $\begin{array}{l}\text { CIVA 5 } \\
\text { (interposition) }\end{array}$ & NS & NS & 0 & NS & Median 10.5 months & NS \\
\hline $\begin{array}{l}\text { Procikieviez } \\
2019^{[14]}\end{array}$ & $\begin{array}{l}\text { CIVA 5 } \\
\text { (interposition) }\end{array}$ & $3(\mathrm{CD} \geq 2)$ & 1 (30 days) & $\begin{array}{l}1 \text { ( }<30 \text { days, died }) \\
0 \text { ( }>30 \text { days })\end{array}$ & $\begin{array}{l}\text { No graft thrombosis or stenosis in } \\
\text { remaining } 4 \text { patients. } \\
\text { Doppler US, CT }\end{array}$ & NS & $\begin{array}{l}\text { LMWH started } 24 \text { hours postoperatively to } \\
\text { prevent DVT (depending on the Caprini } \\
\text { score). ACA } 100 \mathrm{mg} \text { daily from POD } 7 .\end{array}$ \\
\hline Overall & 161 & & $3.2 \%(5 / 156)$ & $\begin{array}{l}\text { Early } 2.5 \%(4 / 161) \\
\text { Late } 3.7 \%(6 / 161) \\
\text { Overall 6.2\% (10/161) } \\
\text { Overall 4.3\% (locoregional } \\
\text { recurrences excluded; } 7 / 161)\end{array}$ & & & \\
\hline
\end{tabular}

ACA: acetyl salicylic acid, CIVA: cadaveric iliacal vein allograft, CD: Clavien Dindo, CT: computer tomography, DVT: deep venous thrombosis, LMWH: low molecular weight heparin, MR: magnetic resonance imaging, NS: not specified, POD: postoperative day, US: ultrasound 
Table 2 Parietal peritoneum and falciform ligament (4 studies)

\begin{tabular}{|c|c|c|c|c|c|c|c|}
\hline Author/Year & $\begin{array}{l}\text { Graft type/ } \\
\text { Number of patients }\end{array}$ & Morbidity & Mortality & Graft thrombosis & Graft patency (n)/Modality & Follow up & Anticoagulation \\
\hline $\begin{array}{l}\text { Dokmak } \\
2015^{[31]}\end{array}$ & $\begin{array}{l}\text { Parietal peritoneum } 18 \text { (patch } \\
15 \text {, near total } 2 \text {, tube made } 1)\end{array}$ & 12 (CD 1-4) & 0 & $\begin{array}{l}1 \text { ( }<30 \text { days, tube made }) \\
0 \text { ( }>30 \text { days })\end{array}$ & $\begin{array}{l}\text { No-mild stenosis }(0-25 \%): 15 \\
\text { Moderate stenosis }(25-75 \%): 2 \\
\text { Severe stenosis/ }(>75 \%): 0 \\
\text { Thrombosis: } 1 \\
\text { CT }\end{array}$ & Mean 14 months & $\begin{array}{l}\text { LMWH } 0.4 \mathrm{~mL}(0.6 \mathrm{~mL} \text { if body mass } \\
\text { index }>35 \mathrm{~kg} / \mathrm{m} 2) \text { for } 4 \text { weeks. }\end{array}$ \\
\hline $\begin{array}{l}\text { Zhiying } \\
2017^{[33]}\end{array}$ & $\begin{array}{l}\text { Falciform ligament } 10 \\
\text { (patch 6, interposition 4) }\end{array}$ & $5(\mathrm{CD} 1-3)$ & 0 & $\begin{array}{l}0 \text { (<30 days) } \\
1 \text { ( }>30 \text { days, occlusion })\end{array}$ & $\begin{array}{l}\text { Complete patency: } 3 \\
\text { Moderate stenosis: } 6 \\
\text { Occlusion: } 1 \\
\text { Doppler US, CT }\end{array}$ & Mean 2 months & None \\
\hline $\begin{array}{l}\text { Shao } \\
2018^{[34]}\end{array}$ & $\begin{array}{l}\text { Falciform ligament } 6 \\
\text { (patch) }\end{array}$ & $2(\mathrm{CD} 2-3)$ & 0 & 0 & $\begin{array}{l}\text { Moderate stenosis: } 1 \\
\text { Doppler US, CT }\end{array}$ & Mean 12 months & None \\
\hline $\begin{array}{l}\text { Malinka } \\
2018^{[32]}\end{array}$ & $\begin{array}{l}\text { Falciform ligament } 11 \\
\text { (patch 9, interposition 2) }\end{array}$ & $6(\mathrm{CD} 2-3)$ & 0 & $\begin{array}{l}2(<30 \text { days, occlusion }) \\
0 \text { ( }>30 \text { days })\end{array}$ & $\begin{array}{l}\text { All patent grafts on discharge }(\mathrm{n}=9) \\
\text { revealed persistent patency. } \\
\text { Doppler US, CT }\end{array}$ & $\begin{array}{l}\text { Median 64 days } \\
\text { (range 18-147) }\end{array}$ & $\begin{array}{l}\text { Unfractionated heparin (goal: partial } \\
\text { thromboplastin time of } 40-50 \text { seconds) } \\
\text { for } 5 \text { days, followed by LMWH to } \\
\text { prevent DVT during hospital stay. }\end{array}$ \\
\hline Overall & 45 & & $\mathbf{0}$ & $\begin{array}{l}\text { Early } 6.7 \%(3 / 45) \\
\text { Late } 2.2 \%(1 / 45) \\
\text { Overall } 8.9 \%(4 / 45)\end{array}$ & & & \\
\hline
\end{tabular}

CD: Clavien Dindo, CT: computer tomography, DVT: deep venous thrombosis, LMWH: low molecular weight heparin, US: ultrasound 
Table 3 Autologous venous grafts (14 studies)

\begin{tabular}{|c|c|c|c|c|c|c|c|c|}
\hline Author & $\begin{array}{l}\text { Graft type/ } \\
\text { Number of patients }\end{array}$ & Morbidity & Mortality & Graft thrombosis & $\begin{array}{l}\text { Graft patency }(\% \text { or } n) / \\
\text { Modality }\end{array}$ & Donor site & Follow up & Anticoagulation \\
\hline $\begin{array}{l}\text { Suzuki } \\
2006^{[24]}\end{array}$ & $\begin{array}{l}\text { Left renal vein } 7 \\
\text { (type NS) }\end{array}$ & NS & 0 & 0 & $\begin{array}{l}100 \% \\
\mathrm{CT}\end{array}$ & $\begin{array}{l}\text { Creatinine levels were not } \\
\text { increased, collateral venous } \\
\text { drainage from the left kidney } \\
\text { was well demonstrated by CT }\end{array}$ & Median 18 months & NS \\
\hline $\begin{array}{l}\text { Smoot } \\
2007^{[22]}\end{array}$ & $\begin{array}{l}\text { Left renal vein } 9 \\
\text { (interposition } 8, \text { patch } 1 \text { ) }\end{array}$ & $3(\mathrm{CD} 1-3)$ & 0 & 0 & $89 \%$ & $\begin{array}{l}\text { Creatinine levels transiently } \\
\text { increased, normalized by } \\
\text { discharge }\end{array}$ & Mean 6.8 months & $\begin{array}{l}\text { Clopidogrel: } 1 \\
\text { Daily ACA: } 8\end{array}$ \\
\hline $\begin{array}{l}\text { Ohwada } \\
2007^{[23]}\end{array}$ & $\begin{array}{l}\text { Left renal vein } 6 \\
\text { (type NS) }\end{array}$ & $3(\mathrm{CD} 1-5)$ & $\begin{array}{l}1 \text { (in-hospital) } \\
\text { (hepatopancreato- } \\
\text { duodenectomy) }\end{array}$ & $\begin{array}{l}2 \text { intraoperatively } \\
\text { (treated with thrombectomy/ } \\
\text { reanastomosis) }\end{array}$ & $100 \%$ & $\begin{array}{l}\text { Creatinine levels were not } \\
\text { increased }\end{array}$ & Mean 22.5 months & $\begin{array}{l}\text { Heparin, followed by } \\
\text { warfarin or ACA }\end{array}$ \\
\hline $\begin{array}{l}\text { Kaneoka } \\
2008^{[27]}\end{array}$ & $\begin{array}{l}\text { External iliac vein } 15 \\
\text { (interposition) }\end{array}$ & NR & 2 (in-hospital) & 0 & $\begin{array}{l}\text { Occlusion: } 1 \\
\text { (received intraoperative } \\
\text { radiation therapy) }\end{array}$ & $\begin{array}{l}\text { Edema of the right leg } \\
\text { present for 1-3 months }\end{array}$ & Mean 32 month & None \\
\hline $\begin{array}{l}\text { Stauffer } \\
2009^{[10]}\end{array}$ & $\begin{array}{l}7 \text { (gonadal or inferior } \\
\text { mesenteric vein) (type NS) }\end{array}$ & NS & NS & 1 (<30 day) & $\begin{array}{l}86 \% \\
\text { Doppler US, CT or MRI }\end{array}$ & NS & $\begin{array}{l}\text { Median } 13.8 \\
\text { months }\end{array}$ & $\begin{array}{l}\text { Standard } \\
\text { thromboprophylaxis } \\
\text { (NS) }\end{array}$ \\
\hline $\begin{array}{l}\text { Lee } \\
2010^{[25]}\end{array}$ & $\begin{array}{l}\text { Femoral vein } 19 \\
\text { Saphenous vein } 15 \\
\text { (interposition } 15, \text { patch 19) }\end{array}$ & 3 DVT & 0 (<30 days $)$ & 2 (<30 days, occlusion) & $\begin{array}{l}88 \% \\
\mathrm{CT}\end{array}$ & $\begin{array}{l}3 \mathrm{FV} \text { : seroma drainage } \\
2 \mathrm{FV} \text { : minor wound dehiscence } \\
8 \mathrm{FV}+1 \mathrm{SV} \text { : minimal transient } \\
\text { edema in ipsilateral leg }\end{array}$ & Mean 5 months & NS \\
\hline $\begin{array}{l}\text { Turley } \\
2012^{[28]}\end{array}$ & $\begin{array}{l}\text { Femoral vein interposition } \\
9 \\
\text { External iliac/Inferior } \\
\text { mesenteric/ Saphenous } \\
\text { patch } 25\end{array}$ & Overall NS & 2 (<30 days $)$ & 1 ( $<30$ days, occlusion) & $\begin{array}{l}91.7 \% \\
\text { Occlusion: } 2 \text { (concomitant } \\
\text { with locoregional } \\
\text { recurrence). Partial } \\
\text { narrowing or occlusion: } 7 \\
\text { CT }\end{array}$ & $\begin{array}{l}\text { FV/EIV: edema in ipsilateral } \\
\text { leg, severe venous } \\
\text { insufficiency } 1 \text {, no permanent } \\
\text { disability } \\
\text { DVT in } 7 \text { patients with FV } \\
\text { interposition }\end{array}$ & $>6$ months & $\begin{array}{l}\text { Routine } \\
\text { thromboprophylaxis } \\
\text { (NS) and ACA }\end{array}$ \\
\hline $\begin{array}{l}\text { Krepline } \\
2014^{[52]}\end{array}$ & $\begin{array}{l}\text { Saphenous vein patch } 9 \\
\text { Internal jugular vein } \\
\text { interposition } 14\end{array}$ & NS & NS & $\begin{array}{l}\text { Early } 0 \text { Late } 1 \\
\text { Early } 1 \text { Late } 1\end{array}$ & $\begin{array}{l}\text { Patent } 8 \\
\text { Patent } 12 \\
\text { Modality NS }\end{array}$ & NS & Median 12 months & $\begin{array}{l}\text { Daily ACA: } 6 \\
\text { LMWH: in selected } \\
\text { cases if indication }\end{array}$ \\
\hline $\begin{array}{l}\text { Hirono } \\
2014^{[26]}\end{array}$ & $\begin{array}{l}\text { External iliac vein } 10 \\
\text { Internal jugular vein } 4 \\
\text { (interposition) }\end{array}$ & $6(\mathrm{CD} 1-4)$ & 2 (in-hospital) & 0 & $\begin{array}{l}\text { No occlusions } \\
\text { Doppler US, CT }\end{array}$ & $\begin{array}{l}3 \text { EIV: DVT ipsilateral leg } \\
1 \text { EIV: leg edema/chronic pain }\end{array}$ & Mean 28.2 months & NS \\
\hline $\begin{array}{l}\text { Glebova } \\
2015^{[18]}\end{array}$ & $\begin{array}{l}11 \text { (internal jugular } 4 \text {, left } \\
\text { renal } 4 \text {, splenic } 2 \text {, } \\
\text { saphenous 1) } \\
\text { (interposition) }\end{array}$ & NS & 0 & 1 (<30 day) & $\begin{array}{l}\text { Patent } 10 \\
\text { CT }\end{array}$ & NS & Median 7 months & None \\
\hline $\begin{array}{l}\text { Dua } \\
2015^{[45]}\end{array}$ & $\begin{array}{l}24 \text { (gonadal 2, internal } \\
\text { jugular } 4 \text {, left renal } 2, \\
\text { saphenous } 6 \text { and femoral } \\
\text { vein 10) (type NS) }\end{array}$ & NS & NS & 8 (time NS) & $\begin{array}{l}\text { NS } \\
\text { Doppler US, CT or MRI }\end{array}$ & NS & Median 8.7 months & $\begin{array}{l}70 \% \text { of patients daily } \\
\text { ACA }\end{array}$ \\
\hline $\begin{array}{l}\text { Loveday } \\
2019^{[21]}\end{array}$ & $\begin{array}{l}\text { Left renal vein } 11 \\
\text { (interposition) }\end{array}$ & $\begin{array}{l}5 \\
\text { (HPB complica } \\
\text { tions) }\end{array}$ & 0 & $\begin{array}{l}4 \text { (thrombus or complication } \\
\text { requiring revision of the } \\
\text { anastomosis) }\end{array}$ & $\begin{array}{l}\text { Patency NS } \\
\text { Modality NS }\end{array}$ & $\begin{array}{l}\text { Acute kidney injury: } \\
\text { POD } 1=5 \text {, POD } 3=3 \text {, resolved } \\
\text { within the first week, no long- }\end{array}$ & $\begin{array}{l}\text { Median } 12.9 \\
\text { months }\end{array}$ & NS \\
\hline
\end{tabular}




\begin{tabular}{|c|c|c|c|c|c|c|c|c|}
\hline & & & & (time NS) & & term sequelae on renal function & & \\
\hline $\begin{array}{l}\text { Pantoja } \\
2019^{[30]}\end{array}$ & $\begin{array}{l}\text { Saphenous vein } 13 \\
\text { Internal jugular vein } 6 \\
\text { (interposition) }\end{array}$ & $\begin{array}{l}4 \\
0\end{array}$ & 0 & $\begin{array}{l}2(<30 \text { days }), 1(>30 \text { days }) \\
2(<30 \text { days })\end{array}$ & $\begin{array}{l}85 \% \\
80 \% \\
\text { Doppler US, CT } \\
\end{array}$ & $\begin{array}{l}\text { Seroma drainage }+ \text { wound } \\
\text { dehiscence }\end{array}$ & $\begin{array}{l}\text { Mean } 17.1 \text { months } \\
\text { Mean } 8.2 \text { months }\end{array}$ & Daily ACA \\
\hline $\begin{array}{l}\text { Terasaki } \\
2019^{[53]}\end{array}$ & $\begin{array}{l}\text { External iliac vein } 25 \\
\text { (interposition) }\end{array}$ & $3(\mathrm{CD}>=3)$ & 0 & 1 (time NS) & $\begin{array}{l}84 \% \\
\text { Doppler US, CT }\end{array}$ & NS & 12 months & $\begin{array}{l}5000 \text { heparin POD } 0, \\
10000 \text { U heparin } \\
\text { POD } 1+2\end{array}$ \\
\hline Overall & 239 & & $2.7 \%(5 / 185)$ & $\begin{array}{l}\text { Early } 5.6 \%(10 / 179) \\
\text { Late } 1.7 \%(3 / 179) \\
\text { Time NS 21.7 \% (13/60) } \\
\text { Overall 11.7\% (28/239) }\end{array}$ & & & & \\
\hline
\end{tabular}

ACA: acetyl salicylic acid, CD: Clavien Dindo, CT: computer tomography, DVT: deep venous thrombosis, LMWH: low molecular weight heparin, NS: not specified, POD: postoperative day, UL: ultrasound 
Table 4 Synthetic (polytetrafluoroethylene) grafts (10 studies)

\begin{tabular}{|c|c|c|c|c|c|c|c|c|}
\hline Author/Year & Graft and $N$ & Morbidity & Mortality & Graft infection & Graft thrombosis & $\begin{array}{l}\text { Graft patency }(\% \text { or } n) / \\
\text { Modality }\end{array}$ & Follow up & Anticoagulation \\
\hline $\begin{array}{l}\text { Smoot } \\
2006^{[39]}\end{array}$ & $\begin{array}{l}\text { PTFE } 18 \\
\text { (patch 2, } \\
\text { interposition 16) }\end{array}$ & NS & 0 & 0 & $\begin{array}{l}1(<30 \text { days }) \\
5(>30 \text { days, associated with, } \\
\text { locoregional recurrence) }\end{array}$ & $\begin{array}{l}\text { NS } \\
\text { Intraoperative US, CT }\end{array}$ & Mean 12.2 months & $\begin{array}{l}\text { Surgeon preference. ACA, warfarin, or } \\
\text { clopidogrel. }\end{array}$ \\
\hline $\begin{array}{l}\text { Stauffer } \\
2009^{[10]}\end{array}$ & $\begin{array}{l}\text { PTFE 10 } \\
\text { (patch 1, } \\
\text { interposition 9) }\end{array}$ & NS & NS & 0 & $\begin{array}{l}1(<30 \text { days }) \\
0(>30 \text { days })\end{array}$ & $\begin{array}{l}100 \% \\
\text { Doppler US, CT or MRI }\end{array}$ & Median 13.8 months & $\begin{array}{l}\text { Standard thromboprophylaxis (NS) plus } 1-2 \\
\text { mg warfarin daily once oral intake was } \\
\text { tolerated for } 3 \text { months. }\end{array}$ \\
\hline $\begin{array}{l}\text { Chu } \\
2010^{[11]}\end{array}$ & $\begin{array}{l}\text { PTFE 33 } \\
\text { (patch 9, } \\
\text { interposition 24) }\end{array}$ & $15(\mathrm{CD} 1-5)$ & $2(30 \mathrm{~d})$ & 0 & $\begin{array}{l}3 \text { ( }<30 \text { days, } 1 \text { died }) \\
5 \text { ( }>30 \text { days, } 4 \text { associated with } \\
\text { concomitant locoregional } \\
\text { recurrence) }\end{array}$ & $\begin{array}{l}77.3 \% \text { at } 6 \text { months }(\mathrm{n}=22) \\
64.3 \% \text { at } 12 \text { months }(\mathrm{n}=14) \\
75.8 \% \text { at last follow up } \\
\text { Doppler US, CT or MRI }\end{array}$ & Mean 14 months & $\begin{array}{l}\text { ACA or LMWH initiated by the time of } \\
\text { discharge, continuation for } 3 \text { to } 6 \text { months. }\end{array}$ \\
\hline $\begin{array}{l}\text { Liao } \\
2014^{[12]}\end{array}$ & $\begin{array}{l}\text { PTFE 34 } \\
\text { (interposition) }\end{array}$ & $10($ CD 1-5) & 1 & 0 & $\begin{array}{l}1(<30 \text { days }) \\
5(>30 \text { days })\end{array}$ & $\begin{array}{l}87.9 \% \text { at } 6 \text { months } \\
83.5 \% \text { at } 12 \text { months } \\
\text { Doppler US, CT or MRI }\end{array}$ & Median 14 months & 11 patients > 70 years: ACA for 3 months \\
\hline $\begin{array}{l}\text { Glebova } \\
2015^{[18]} \\
\end{array}$ & $\begin{array}{l}\text { PTFE or Dacron } 6 \\
\text { (interposition) }\end{array}$ & NS & 0 & 0 & 3 early/late NS & $\begin{array}{l}\text { Patent: } 3 \\
\text { CT } \\
\end{array}$ & Median 7 months & None \\
\hline $\begin{array}{ll}\text { Flis } \\
2016^{[54]}\end{array}$ & $\begin{array}{l}\text { Dacron } 8 \\
\text { (interposition) }\end{array}$ & NS & NS & 0 & 0 & NS & NS & NS \\
\hline $\begin{array}{l}\text { Gao } \\
2016^{[55]}\end{array}$ & $\begin{array}{l}\text { PTFE 7 } \\
\text { (interposition) }\end{array}$ & 6 & 0 & $\begin{array}{l}0 \text { (encapsulated } \\
\text { effusion around } \\
\text { graft } 1 \text {, edema } \\
\text { around graft } 1 \text { ) }\end{array}$ & $\begin{array}{l}2^{*}(<30 \text { days }) \\
4^{*}(>30 \text { days }) \\
(* \text { one patient both early and late })\end{array}$ & $\begin{array}{l}\text { Stenosis }(>50 \%) \\
2(<30 \text { days }), \\
3 \text { (> 30 days) } \\
\text { Doppler US, CT }\end{array}$ & Median 12 months & $\begin{array}{l}\text { LMWH for } 2 \text { weeks after surgery, } \\
\text { followed by oral warfarin for } 6 \text { months }\end{array}$ \\
\hline $\begin{array}{l}\text { Dumitrascu } \\
2018^{[51]} \\
\end{array}$ & $\begin{array}{l}\text { PTFE } 19 \\
\text { (interposition) } \\
\end{array}$ & NS & NS & NS & 3 early/late NS & NS & Median 10.5 months & (2) \\
\hline $\begin{array}{l}\text { Wang } \\
2019^{[56]}\end{array}$ & $\begin{array}{l}\text { PTFE 10 } \\
\text { (interposition) }\end{array}$ & $4(\mathrm{CD} 1+2)$ & 0 & 0 & $\begin{array}{l}2(<30 \text { days }) \\
0(>30 \text { days }) \\
\end{array}$ & $\begin{array}{l}100 \% \text { at } 2 \text { months } \\
\text { CT }\end{array}$ & NS & $\begin{array}{l}\text { LMWH for } 7 \text { days after surgery, } \\
\text { followed by oral warfarin (INR 1.5-2) }\end{array}$ \\
\hline $\begin{array}{l}\text { Tsiotos } \\
2019^{[57]}\end{array}$ & $\begin{array}{l}\text { PTFE } 13 \\
\text { (interposition) }\end{array}$ & NS & NS & 0 & 0 & $\begin{array}{l}100 \% \\
\text { Doppler US }\end{array}$ & $\begin{array}{l}2 \text { months } \\
\text { Doppler US }\end{array}$ & \\
\hline Overall & 158 & & $\begin{array}{l}2.7 \% \\
(3 / 108)\end{array}$ & $\mathbf{0}$ & $\begin{array}{l}\text { Early } 7.5 \%(10 / 133) \\
\text { Late } 14.3 \%(19 / 133) \\
\text { Time NS } 24 \%(6 / 25) \\
\text { Overall } 22.2 \%(35 / 158) \\
\text { Overall } 16.4 \% \text { (locoregional } \\
\text { recurrences excluded; 26/158) }\end{array}$ & & & \\
\hline
\end{tabular}

ACA: acetyl salicylic acid, CD: Clavien Dindo, CT: computer tomography, INR: international normalized ratio, LMWH: low molecular weight heparin, MRI: magnetic resonance imaging, NS: not specified, POD: postoperative day, PTFE: Polytetrafluoroethylene, UL: ultrasound 
Table S1

Quality assessment of included articles based on the Newcastle-Ottawa Scale (NOS)

\begin{tabular}{|c|c|c|c|c|c|c|c|c|c|c|c|}
\hline \multirow[t]{2}{*}{ Study } & \multirow[t]{2}{*}{ Year } & \multicolumn{4}{|c|}{ Selection } & \multicolumn{2}{|c|}{ Comparability } & \multicolumn{2}{|c|}{ Exposure } & \multirow[b]{2}{*}{ E3 } & \multirow[t]{2}{*}{ No. of stars } \\
\hline & & S1 & S2 & S3 & $\mathbf{S 4}$ & C1 & $\mathrm{C2}$ & E1 & E2 & & \\
\hline \multicolumn{12}{|c|}{ Cadaveric vein or arterial allografts } \\
\hline Zhang & 2013 & $*$ & NR & $*$ & $*$ & NR & NR & $*$ & $*$ & $*$ & 6 \\
\hline Mascoli & 2015 & $*$ & NR & $*$ & $*$ & NR & NR & * & $*$ & $*$ & 6 \\
\hline Kleive & 2016 & $*$ & NR & $*$ & $*$ & NR & NR & $*$ & $*$ & - & 5 \\
\hline Zhao & 2016 & $*$ & NR & $*$ & $*$ & NR & NR & $*$ & $*$ & - & 5 \\
\hline Meniconi & 2016 & $*$ & NR & $*$ & $*$ & NR & NR & $*$ & $*$ & $*$ & 6 \\
\hline Yamamoto & 2017 & $*$ & NR & $*$ & $*$ & NR & NR & $*$ & $*$ & $*$ & 6 \\
\hline Zhang & 2018 & $*$ & NR & $*$ & $*$ & NR & NR & $*$ & $*$ & $*$ & 6 \\
\hline Dumitrascu & 2018 & $*$ & NR & $*$ & $*$ & NR & NR & - & $*$ & - & 4 \\
\hline Procikieviez & 2019 & $*$ & NR & $*$ & $*$ & NR & NR & $*$ & $*$ & $*$ & 6 \\
\hline \multicolumn{12}{|c|}{$\underline{\text { Parietal peritoneum and falciform ligament }}$} \\
\hline Dokmak & 2015 & $*$ & NR & $*$ & $*$ & NR & $\mathrm{NR}$ & - * & $*$ & $*$ & 6 \\
\hline Zhiying & 2017 & $*$ & NR & $*$ & $*$ & NR & NR & $*$ & $*$ & $*$ & 6 \\
\hline Shao & 2018 & $*$ & NR & $*$ & $*$ & NR & NR & $*$ & $*$ & $*$ & 6 \\
\hline Malinka & 2018 & $*$ & NR & $*$ & $*$ & NR & NR & $*$ & $*$ & - & 5 \\
\hline \multicolumn{12}{|c|}{$\underline{\text { Autologous venous grafts }}$} \\
\hline Suzuki & 2006 & $*$ & NR & $*$ & $*$ & NR & NR & $*$ & $*$ & $*$ & 6 \\
\hline Smoot & 2007 & $*$ & NR & $*$ & $*$ & NR & NR & - & $*$ & $*$ & 5 \\
\hline Ohwada & 2007 & $*$ & NR & $*$ & $*$ & NR & NR & - & $*$ & - & 4 \\
\hline Kaneoka & 2008 & $*$ & NR & $*$ & $*$ & NR & NR & - & $*$ & - & 4 \\
\hline Stauffer & 2009 & $*$ & NR & $*$ & $*$ & NR & NR & $*$ & $*$ & $*$ & 6 \\
\hline Lee & 2010 & $*$ & NR & $*$ & $*$ & NR & NR & - & $*$ & - & 4 \\
\hline Turley & 2012 & $*$ & NR & $*$ & $*$ & NR & NR & - & $*$ & $*$ & 5 \\
\hline Krepline & 2014 & $*$ & NR & $*$ & $*$ & NR & NR & $*$ & $*$ & $*$ & 6 \\
\hline Hirono & 2014 & $*$ & NR & $*$ & $*$ & NR & NR & $*$ & $*$ & $*$ & 6 \\
\hline Glebova & 2015 & $*$ & NR & $*$ & $*$ & NR & NR & $*$ & $*$ & $*$ & 6 \\
\hline Dua & 2015 & $*$ & NR & $*$ & $*$ & NR & NR & $*$ & $*$ & $*$ & 6 \\
\hline Loveday & 2019 & $*$ & NR & $*$ & $*$ & NR & NR & - & $*$ & - & 4 \\
\hline Pantoja & 2019 & $*$ & NR & $*$ & $*$ & NR & NR & - & $*$ & $*$ & 5 \\
\hline Terasaki & 2019 & $*$ & NR & $*$ & $*$ & NR & NR & $*$ & $*$ & $*$ & 6 \\
\hline \multicolumn{12}{|c|}{ Synthetic grafts } \\
\hline Smoot & 2006 & $*$ & NR & $*$ & $*$ & NR & NR & $*$ & $*$ & $*$ & 6 \\
\hline Stauffer & 2009 & $*$ & NR & $*$ & $*$ & NR & NR & $*$ & $*$ & $*$ & 6 \\
\hline Chu & 2010 & $*$ & NR & $*$ & $*$ & NR & NR & $*$ & $*$ & - & 5 \\
\hline Liao & 2014 & $*$ & NR & $*$ & $*$ & NR & NR & $*$ & $*$ & $*$ & 6 \\
\hline Glebova & 2015 & $*$ & NR & $*$ & $*$ & NR & NR & $*$ & $*$ & $*$ & 6 \\
\hline Flis & 2016 & $*$ & NR & $*$ & $*$ & NR & NR & - & $*$ & $*$ & 5 \\
\hline Gao & 2016 & $*$ & NR & $*$ & $*$ & NR & NR & $*$ & $*$ & $*$ & 6 \\
\hline Dumitrascu & 2018 & $*$ & NR & $*$ & $*$ & NR & NR & - & $*$ & - & 4 \\
\hline Wang & 2019 & $*$ & NR & $*$ & $*$ & NR & NR & - & $*$ & $*$ & 5 \\
\hline Tsiotos & 2019 & $*$ & NR & $*$ & $*$ & NR & NR & - & $*$ & - & 4 \\
\hline
\end{tabular}

*No. of stars given= relevant score possibility; S1, How representative is the exposed cohort?; S2, Selection of the non-exposed cohort?; S3, Ascertainment of exposure?; S4, Outcome not present at start of study?; C1, Comparability of outcome?; C2, Comparability of the design?; E1, Assessment of outcome?; E2, Sufficiently long follow-up for outcome to occur?; E3, Adequacy of follow-up?; NR=Not relevant 


\section{REFERENCES}

1 Ravikumar R, Sabin C, Abu Hilal M, Al-Hilli A, Aroori S, Bond-Smith G, et al. Impact of portal vein infiltration and type of venous reconstruction in surgery for borderline resectable pancreatic cancer. Br J Surg 2017;104:1539-1548

2 Kleive D, Labori KJ, Line PD, Gladhaug IP, Verbeke CS. Pancreatoduodenectomy with venous resection for ductal adenocarcinoma rarely achieves complete (R0) resection. HPB (Oxford) 2020;22:50-57

3 Kleive D, Berstad AE, Verbeke CS, Haugvik SP, Gladhaug IP, Line PD, et al. Coldstored cadaveric venous allograft for superior mesenteric/portal vein reconstruction during pancreatic surgery. HPB (Oxford) 2016;18:615-622

4 Groen JV, Stommel MWJ, Sarasqueta AF, Besselink MG, Brosens LAA, van Eijck $\mathrm{CHJ}$, et al. Surgical management and pathological assessment of pancreatoduodenectomy with venous resection: an international survey among surgeons and pathologists. HPB (Oxford) 2020

5 Wang F, Arianayagam R, Gill A, Puttaswamy V, Neale M, Gananadha S, et al. Grafts for mesenterico-portal vein resections can be avoided during pancreatoduodenectomy. $\mathrm{J}$ Am Coll Surg 2012;215:569-579

6 Del Chiaro M, Segersvard R, Rangelova E, Coppola A, Scandavini CM, Ansorge C, et al. Cattell-Braasch Maneuver Combined with Artery-First Approach for Superior MesentericPortal Vein Resection During Pancreatectomy. J Gastrointest Surg 2015;19:2264-2268 7 Moher D, Liberati A, Tetzlaff J, Altman DG, Group P. Preferred reporting items for systematic reviews and meta-analyses: the PRISMA statement. Int J Surg 2010;8:336-341 8 Song W, Yang Q, Chen L, Sun Q, Zhou D, Ye S, et al. Pancreatoduodenectomy combined with portal-superior mesenteric vein resection and reconstruction with interposition grafts for cancer: a meta-analysis. Oncotarget 2017;8:81520-81528 
9 Wells GA, Shea B, O’'Connel D, Peterson;J., Welch V, Losos;M., et al. The

Newcastle-Ottawa Scale (NOS) for assessing the quality of nonrandomised studies in metaanalyses. http://www.ohri.ca/programs/clinical_epidemiology/oxford.asp [accessed 15 May 2020]

10 Stauffer JA, Dougherty MK, Kim GP, Nguyen JH. Interposition graft with polytetrafluoroethylene for mesenteric and portal vein reconstruction after pancreaticoduodenectomy. Br J Surg 2009;96:247-252

11 Chu CK, Farnell MB, Nguyen JH, Stauffer JA, Kooby DA, Sclabas GM, et al. Prosthetic graft reconstruction after portal vein resection in pancreaticoduodenectomy: a multicenter analysis. J Am Coll Surg 2010;211:316-324

12 Liao K, Wang H, Chen Q, Wu Z, Zhang L. Prosthetic graft for superior mesentericportal vein reconstruction in pancreaticoduodenectomy: a retrospective, multicenter study. J Gastrointest Surg 2014;18:1452-1461

13 Meniconi RL, Santoro R, Guglielmo N, Vennarecci G, Lepiane P, Colasanti M, et al. Pancreaticoduodenectomy with venous reconstruction using cold-stored vein allografts: longterm results of a single center experience. J Hepatobiliary Pancreat Sci 2016;23:43-49 14 Procikieviez IO, Alcaraz A, Reimondez S, Segade EG, Signorini F, Maraschio M, et al. Vein reconstruction with cryopreserved vein allograft in pancreaticoduodenectomy. Pancreatic surgery. Acta Gastroenterol Latinoam 2019;49:336-340.336 15 Chandrasegaram MD, Eslick GD, Lee W, Brooke-Smith ME, Padbury R, Worthley CS, et al. Anticoagulation policy after venous resection with a pancreatectomy: a systematic review. HPB (Oxford) 2014;16:691-698

16 Kantor O, Talamonti MS, Wang CH, Roggin KK, Bentrem DJ, Winchester DJ, et al. The extent of vascular resection is associated with perioperative outcome in patients undergoing pancreaticoduodenectomy. HPB (Oxford) 2018;20:140-146 
17 Gage MM, Reames BN, Ejaz A, Sham J, Fishman EK, Weiss MJ, et al.

Pancreaticoduodenectomy with en bloc vein resection for locally advanced pancreatic cancer: a case series without venous reconstruction. Chin Clin Oncol 2018;7:7

18 Glebova NO, Hicks CW, Piazza KM, Abularrage CJ, Cameron AM, Schulick RD, et al. Technical risk factors for portal vein reconstruction thrombosis in pancreatic resection. $\mathrm{J}$ Vasc Surg 2015;62:424-433

19 Kleive D, Berstad AE, Sahakyan MA, Verbeke CS, Naper C, Haugvik SP, et al. Portal vein reconstruction using primary anastomosis or venous interposition allograft in pancreatic surgery. J Vasc Surg Venous Lymphat Disord 2018;6:66-74

20 Yan S, Zhang Q, Cai M, Yu D, Chen J, Yu P, et al. A novel model of portal vein transplantation in mice using two-cuff technique. Microsurgery 2007;27:569-574

21 Loveday BPT, Dib MJ, Sequeira S, Alotaiby N, Visser R, Barbas AS, et al. Renal outcomes following left renal vein harvest for venous reconstruction during pancreas and liver surgery. HPB (Oxford) 2019;21:114-120

22 Smoot RL, Christein JD, Farnell MB. An innovative option for venous reconstruction after pancreaticoduodenectomy: the left renal vein. J Gastrointest Surg 2007;11:425-431

23 Ohwada S, Hamada K, Kawate S, Sunose Y, Tomizawa N, Yamada T, et al. Left renal vein graft for vascular reconstruction in abdominal malignancy. World J Surg 2007;31:12151220

24 Suzuki T, Yoshidome H, Kimura F, Shimizu H, Ohtsuka M, Kato A, et al. Renal Function Is Well Maintained after Use of Left Renal Vein Graft for Vascular Reconstruction in Hepatobiliary-Pancreatic Surgery. J Am Coll Surg 2006;202:87-92

25 Lee DY, Mitchell EL, Jones MA, Landry GJ, Liem TK, Sheppard BC, et al. Techniques and results of portal vein/superior mesenteric vein reconstruction using femoral and saphenous vein during pancreaticoduodenectomy. J Vasc Surg 2010;51:662-666 
26 Hirono S, Kawai M, Tani M, Okada K, Miyazawa M, Shimizu A, et al. Indication for the use of an interposed graft during portal vein and/or superior mesenteric vein reconstruction in pancreatic resection based on perioperative outcomes. Langenbecks Arch Surg 2014;399:461-471

27 Kaneoka Y, Yamaguchi A, Isogai M. Portal or superior mesenteric vein resection for pancreatic head adenocarcinoma: prognostic value of the length of venous resection. Surgery 2009;145:417-425

28 Turley RS, Peterson K, Barbas AS, Ceppa EP, Paulson EK, Blazer DG, 3rd, et al. Vascular surgery collaboration during pancreaticoduodenectomy with vascular reconstruction. Ann Vasc Surg 2012;26:685-692

29 Yoshioka M, Uchinami H, Watanabe G, Iida M, Nakagawa Y, Miyazawa H, et al. Domino Reconstruction of the Portal Vein Using the External Iliac Vein and an ePTFE Graft in Pancreatic Surgery. J Gastrointest Surg 2017;21:1278-1286

30 Pantoja JL, Chang K, Pellionisz PA, Woo K, Farley SM. Paneled Saphenous Vein Grafts Compared to Internal Jugular Vein Grafts in Venous Reconstruction after Pancreaticoduodenectomy. Ann Vasc Surg 2020;65:17-24

31 Dokmak S, Aussilhou B, Sauvanet A, Nagarajan G, Farges O, Belghiti J. Parietal Peritoneum as an Autologous Substitute for Venous Reconstruction in Hepatopancreatobiliary Surgery. Ann Surg 2015;262:366-371

32 Malinka T, Klein F, Denecke T, Pelzer U, Pratschke J, Bahra M. The Falciform Ligament for Mesenteric and Portal Vein Reconstruction in Local Advanced Pancreatic Tumor: A Surgical Guide and Single-Center Experience. HPB Surg 2018;2018:2943879 33 Zhiying Y, Haidong T, Xiaolei L, Yongliang S, Shuang S, Liguo L, et al. The falciform ligament as a graft for portal-superior mesenteric vein reconstruction in pancreatectomy. J Surg Res 2017;218:226-231 
34 Shao Y, Yan S, Zhang QY, Shen Y, Zhang M, Wang WL, et al. Autologous falciform ligament graft as A substitute for mesentericoportal vein reconstruction in pancreaticoduodenectomy. Int J Surg 2018;53:159-162

35 Jara M, Malinowski M, Bahra M, Stockmannn M, Schulz A, Pratschke J, et al. Bovine pericardium for portal vein reconstruction in abdominal surgery: a surgical guide and first experiences in a single center. Dig Surg 2015;32:135-141

36 Rochon C, Sheiner PA, Sharma J, Rodriguez-Davalos MI, Savino J, Facciuto ME. The utility of recanalized umbilical vein graft to the hepato-pancreato-biliary surgeon. Surg Innov $2013 ; 20: 126-133$

37 Al-Hawary MM, Francis IR, Chari ST, Fishman EK, Hough DM, Lu DS, et al. Pancreatic ductal adenocarcinoma radiology reporting template: consensus statement of the society of abdominal radiology and the american pancreatic association. Gastroenterology 2014;146:291-304 e291

38 Kim PT, Wei AC, Atenafu EG, Cavallucci D, Cleary SP, Moulton CA, et al. Planned versus unplanned portal vein resections during pancreaticoduodenectomy for adenocarcinoma. Br J Surg 2013;100:1349-1356

39 Smoot RL, Christein JD, Farnell MB. Durability of portal venous reconstruction following resection during pancreaticoduodenectomy. J Gastrointest Surg 2006;10:1371-1375 40 Snyder RA, Prakash LR, Nogueras-Gonzalez GM, Kim MP, Aloia TA, Vauthey JN, et al. Vein resection during pancreaticoduodenectomy for pancreatic adenocarcinoma: Patency rates and outcomes associated with thrombosis. J Surg Oncol 2018;117:1648-1654

41 Javed AA, Bleich K, Bagante F, He J, Weiss MJ, Wolfgang CL, et al. Pancreaticoduodenectomy with venous resection and reconstruction: current surgical techniques and associated postoperative imaging findings. Abdom Radiol (NY) 2018;43:1193-1203 
42 Kang MJ, Jang JY, Chang YR, Jung W, Kim SW. Portal vein patency after pancreatoduodenectomy for periampullary cancer. Br J Surg 2015;102:77-84

43 Khan A, Kleive D, Aandahl EM, Fosby B, Line PD, Dorenberg E, et al. Portal vein stent placement after hepatobiliary and pancreatic surgery. Langenbecks Arch Surg 2020;405:657-664

44 Kleive D, Sahakyan M, Soreide K, Brudvik KW, Line PD, Gladhaug IP, et al. Risk for hemorrhage after pancreatoduodenectomy with venous resection. Langenbecks Arch Surg 2018;403:949-957

45 Dua MM, Tran TB, Klausner J, Hwa KJ, Poultsides GA, Norton JA, et al. Pancreatectomy with vein reconstruction: technique matters. HPB (Oxford) 2015;17:824-831 46 Zhang Q, Yan S, Wang W, Shen Y, Zhang M, Ding Y, et al. Use of allograft for portomesenteric vein interposition in radical resection of pancreatic tumor. Surgical Practice 2013:22-27

47 Mascoli C, D"Ambra M, Casadei R, Ricci C, Taffurelli G, Ancetti S, et al. Portal/Superior Mesenteric Vein Reconstruction during Pancreatic Resection Using a Cryopreserved Arterial Homograft. Dig Surg 2015;32:284-290

48 Zhao X, Li LX, Fan H, Kou JT, Li XL, Lang R, et al. Segmental portal/superior mesenteric vein resection and reconstruction with the iliac vein after pancreatoduodenectomy. J Int Med Res 2016;44:1339-1348

49 Yamamoto M, Akamatsu N, Aoki T, Sakamoto Y, Tamura S, Hasegawa K, et al. Safety and efficacy of cryopreserved homologous veins for venous reconstruction in pancreatoduodenectomy. Surgery 2017;161:385-393

50 Zhang XM, Zhang J, Fan H, He Q, Lang R. Feasibility of portal or superior mesenteric vein resection and reconstruction by allogeneic vein for pancreatic head cancer-a case-control study. BMC Gastroenterol 2018;18:49 
51 Dumitrascu T, Martiniuc A, Brasoveanu V, Stroescu C, David L, Dima S, et al. One Hundred Pancreatectomies with Venous Resection for Pancreatic Adenocarcinoma. Chirurgia (Bucur) 2018;113:363-373

52 Krepline AN, Christians KK, Duelge K, Mahmoud A, Ritch P, George B, et al. Patency rates of portal vein/superior mesenteric vein reconstruction after pancreatectomy for pancreatic cancer. J Gastrointest Surg 2014;18:2016-2025

53 Terasaki F, Fukami Y, Maeda A, Takayama Y, Takahashi T, Uji M, et al. Comparison of end-to-end anastomosis and interposition graft during pancreatoduodenectomy with portal vein reconstruction for pancreatic ductal adenocarcinoma. Langenbecks Arch Surg 2019;404:191-201

54 Flis V, Potrc S, Kobilica N, Ivanecz A. Pancreaticoduodenectomy for ductal adenocarcinoma of the pancreatic head with venous resection. Radiol Oncol 2016;50:321-328 55 Gao W, Dai X, Dai C, Jiang K, Wu J, Li Q, et al. Comparison of patency rates and clinical impact of different reconstruction methods following portal/superior mesenteric vein resection during pancreatectomy. Pancreatology 2016;16:1113-1123

56 Wang X, Cai Y, Zhao W, Gao P, Li Y, Liu X, et al. Laparoscopic pancreatoduodenectomy combined with portal-superior mesenteric vein resection and reconstruction with interposition graft: Case series. Medicine (Baltimore) 2019;98:e14204 57 Tsiotos GG, Ballian N, Michelakos T, Milas F, Ziogou P, Papaioannou D, et al. Portal-Mesenteric Vein Resection in Borderline Pancreatic Cancer; 33 Month-Survival in Patients with Good Performance Status. J Pancreat Cancer 2019;5:43-50 